\title{
Chelated zinc leaf application on nutrients concentration and yield of Mombasa grass
}

Natália Martins Teixeira, Reges Heinrichs, Carolina Santos B. Bonini, Joshua Afzal, Guilherme Constantino Meirelles, Cecilio Viega Soares Filho \& Adônis Moreira

To cite this article: Natália Martins Teixeira, Reges Heinrichs, Carolina Santos B. Bonini, Joshua Afzal, Guilherme Constantino Meirelles, Cecilio Viega Soares Filho \& Adônis Moreira (2019) Chelated zinc leaf application on nutrients concentration and yield of Mombasa grass, Journal of Plant Nutrition, 42:1, 89-98, DOI: 10.1080/01904167.2018.1549673

To link to this article: https://doi.org/10.1080/01904167.2018.1549673

曲 Published online: 31 Dec 2018.

Submit your article to this journal $๘$

Џll Article views: 44

View Crossmark data \lceil 


\title{
Chelated zinc leaf application on nutrients concentration and yield of Mombasa grass
}

\author{
Natália Martins Teixeira ${ }^{a}$, Reges Heinrichs ${ }^{a}$, Carolina Santos B. Bonini ${ }^{a}$, Joshua Afzal ${ }^{b}$, \\ Guilherme Constantino Meirelles ${ }^{a}$, Cecilio Viega Soares Filhoc ${ }^{c}$ and Adônis Moreira ${ }^{d}$ \\ ${ }^{a}$ Department of Animal Science Technology, São Paulo State University, FCAT/UNESP, Dracena, Brazil; \\ ${ }^{\mathrm{b}}$ Department of Crop Science, Hohenheim University Stuttgart, Germany; ' Department of Animal Science \\ Technology, São Paulo State University, FCAT/UNESP, Araçatuba; ${ }^{d}$ Department of Soil Science, Embrapa Soja, \\ Londrina, Brazil
}

\begin{abstract}
The intensification of livestock yield requires advances in the management and fertilization of forage crops. This study was conducted to determine the dry weight yield (DWY) along with the concentration and amount of nutrients of Megathyrsus maximum cv. Mombasa. The treatments were arranged in a factorial scheme $6 \times 2$, six leaf rates of $\mathrm{Zn}$ chelate and two soil types (Entisols and Ultisol) with low and medium $\mathrm{Zn}$ content and four replicates. Entisols with low $\mathrm{Zn}$ content and Ultisol with average $\mathrm{Zn}$ content were used plus a control treatment with $\mathrm{Zn}$ sulfate. The $\mathrm{Zn}$ chelate and $\mathrm{Zn}$ sulfate foliar application did not affect the DWY. The tillering and DWY were higher in Ultisol than in Entisol. The $\mathrm{Zn}$ content in DWY was directly proportional to rate chelated $\mathrm{Zn}$. The root dry weight yield of Mombasa grass reduced with the chelated $\mathrm{Zn}$ foliar application in Entisol and had no effect on Ultisol.
\end{abstract}

\section{ARTICLE HISTORY}

Received 16 October 2017

Accepted 8 May 2018

\section{KEYWORDS}

Pasture; forage; nutritional status; zinc fertilization

\section{Introduction}

The cattle industry is one in which productivity, efficiency, profitability, and the sustainability of production processes are aspects of great importance. As a result, there is currently an intensification of production, with fertilizers being used to increase both the productivity and quality of pastures. This should result in a greater demand for micronutrients in the system (Manoj et al. 2016). In addition, the study of micronutrients in pastures is important for mineral nutrition of plants and the nutrition of animals that feed on the forage.

Pastures are the main food source for herds of ruminants, which constitute the support base of Brazilian livestock. Megathyrsus maximum (syn. Panicum maximum), varieties Tanzania and Mombasa, are among the innovative forage responsible for the technological leap which have increased productivity per area, as well as the nutritional value of the pastures' production system (Moreno et al. 2014; Heinrichs et al. 2016). To complement the soil fertilization, foliar fertilization is also used. This is traditionally intended for correction of nutrient deficiencies. It is also a good alternative to using small rates and reducing common losses in soil fertilization, such as leaching and immobilization (Boonchuay et al. 2013).

Micronutrients are indispensable for the growth and development of plants. However, their use in tropical grass pasture fertilization programs does not always result in an increase of forage 
yield. This lack of response may occur because the soils with low $\mathrm{pH}$, with no liming or low fertilization with macronutrients and micronutrients application in the soil may also lead to a lack of response (Guimarães et al. 2016).

The primary cause of nutritional deficiency is the low concentration of $\mathrm{Zn}$ in soil, compounded by the intensification of the removal of the micronutrient crops and in some situations, the excessive increase in soil $\mathrm{pH}$ by liming. At high $\mathrm{pH}$ levels, the availability of $\mathrm{Zn}$ for plants decreases due to reduced solubility and redistribution of micronutrients of exchangeable fraction for oxidic fractions ( $\mathrm{Fe}$ oxides and crystalline and amorphous $\mathrm{Al}$ ) less available to plants (Jha et al. 2015).

The objective of this study was to evaluate the SDW, root dry weight, nutrients concentration and amount of the forage Megathyrsus maximum cv. Mombasa fertilized with $\mathrm{Zn}$ chelated leaf application, in two soils (Entisols and Ultisol) with different $\mathrm{Zn}$ availabilities.

\section{Materials and methods}

\section{Forage plant and soil}

The experiment was conducted in a greenhouse at São Paulo State University, $\left(21^{\circ} 29^{\prime}\right.$ LS and $51^{\circ} 32^{\prime} \mathrm{LW} ; 396 \mathrm{~m}$ altitude), Dracena county, Brazil, using the forage grass Megathyrsus maximum cv. Mombasa. Two soils were used (Embrapa 2013): i) Entisol: dystrophic, with Cerrado vegetation, with the following chemical attributes: $\mathrm{pH} 4.0$ [calcium chloride $\left(\mathrm{CaCl}_{2} 0.1 \mathrm{~mol} \mathrm{~L}^{-1}\right)$ ], $7.0 \mathrm{~g}$ $\mathrm{kg}^{-1}$ organic matter (OM), $3.0 \mathrm{mg} \mathrm{kg}^{-1}$ phosphorus (P) (resin-extracted), $7.0 \mathrm{mg} \mathrm{kg}^{-1}$ sulfur (S)sulfate $\left(\mathrm{SO}_{4}{ }^{2-}\right), 0.1 \mathrm{mmol}_{\mathrm{c}} \mathrm{kg}^{-1}$ potassium $\left(\mathrm{K}^{+}\right), 3.0 \mathrm{mmol}_{\mathrm{c}} \mathrm{kg}^{-1}$ calcium $\left(\mathrm{Ca}^{2+}\right), 2.0 \mathrm{mmol}_{\mathrm{c}} \mathrm{kg}^{-1}$ magnesium $\left(\mathrm{Mg}^{2+}\right), 3.0 \mathrm{mmol}_{\mathrm{c}} \mathrm{kg}^{-1}$ aluminum $\left(\mathrm{Al}^{3+}\right), 25.0 \mathrm{mmol}_{\mathrm{c}} \mathrm{kg}^{-1}$ potential acidity $\left(\mathrm{H}^{+}+\mathrm{Al}^{3+}\right), 30.0 \mathrm{mmol}_{\mathrm{c}} \mathrm{kg}^{-1}$ cation exchange capacity (CEC), $17 \%$ base saturation $(\mathrm{V}), 0.3 \mathrm{mg}$ $\mathrm{kg}^{-1}$ boron (B), $0.5 \mathrm{mg} \mathrm{kg}{ }^{-1}$ copper $(\mathrm{Cu}), 73 \mathrm{mg} \mathrm{kg}^{-1}$ iron ( $\left.\mathrm{Fe}\right), 1.1 \mathrm{mg} \mathrm{kg}^{-1}$ manganese (Mn), and $0.3 \mathrm{mg} \mathrm{kg}^{-1} \mathrm{Zn}$. b) Ultisol, dystrophic, with $\mathrm{pH} 5.2\left(\mathrm{CaCl}_{2} 0.1 \mathrm{~mol} \mathrm{~L}{ }^{-1}\right), 5.0 \mathrm{~g} \mathrm{~kg}^{-1} \mathrm{OM}$; $5.0 \mathrm{mg} \mathrm{kg}^{-1} \mathrm{P}$ (resin-extracted), $7.0 \mathrm{mg} \mathrm{kg}^{-1} \mathrm{~S} ; 2.3 \mathrm{mmol}_{\mathrm{c}} \mathrm{kg}^{-1} \mathrm{~K}^{+}, 10.0 \mathrm{mmol}_{\mathrm{c}} \mathrm{kg}^{-1} \mathrm{Ca}^{2+}$, $3.0 \mathrm{mmol}_{\mathrm{c}} \mathrm{kg}^{-1} \mathrm{Mg}^{2+}, 0.1 \mathrm{mmol}_{\mathrm{c}} \mathrm{kg}^{-1} \mathrm{Al}^{3+} ; 18.0 \mathrm{mmol}_{\mathrm{c}} \mathrm{kg}^{-1} \mathrm{H}^{+}+\mathrm{Al}^{3+} ; 33.0 \mathrm{mmol}_{\mathrm{c}} \mathrm{kg}^{-1}$ cation exchange capacity (CEC), $46 \% \mathrm{~V}, 0.3 \mathrm{mg} \mathrm{kg}{ }^{-1} \mathrm{~B}, 1.6 \mathrm{mg} \mathrm{kg}^{-1} \mathrm{Cu} ; 10 \mathrm{mg} \mathrm{kg}^{-1} \mathrm{Fe}, 4.2 \mathrm{mg}$ $\mathrm{kg}^{-1} \mathrm{Mn}$, and $0.8 \mathrm{mg} \mathrm{kg}^{-1} \mathrm{Zn}$ (Raij et al. 2001). In this experiment, soils were sampled from a $0-20 \mathrm{~cm}$ depth for a composite sample; the soil was crumbled, air-dried and then sieved $(4.0 \mathrm{~mm})$.

\section{Experimental design and treatments}

The experiment was arranged in a completely randomized block design with four replicates. The $6 \times 2$ factorial treatments consisted of six foliar zinc chelates (EDTA) rates 0.0, 43.5, 87.0, 174.0, 348.0, and $696.0 \mathrm{~g}$ applied with $200 \mathrm{~L} \mathrm{ha}^{-1}$ of $\mathrm{H}_{2} \mathrm{O}$, in two soil conditions [low (Entisol) and high zinc content (Ultisol)], plus a control treatment with zinc sulfate (PA reagent, with $355.6 \mathrm{~g} 200 \mathrm{~L}$ $\mathrm{ha}^{-1}$ of $\left.\mathrm{Zn}\right)$.

\section{Experimental conditions and plant growth}

The base saturation of soils was increased to $70 \%$ (Raij et al. 1996) by adding $\mathrm{CaCO}_{3}$ and magnesium carbonate $\left(\mathrm{MgCO}_{3}\right)$, P.A. reagents at a ratio of $3: 1$. The soils plus carbonate salts were then incubated for 30 days in the pots for the reaction, with moisture maintained at $80 \%$ field capacity. At the end of the incubation period, the soils were air-dried for seven days. The soils of each pot ( $4.0 \mathrm{~kg}$ with soil density of $1.3 \mathrm{~g} \mathrm{~cm}^{-3}$ ) were transferred to plastic trays where the treatments and fertilizers were applied: ammonium nitrate $\left(\mathrm{NH}_{4} \mathrm{NO}_{3}\right)$, with $300.0 \mathrm{mg} \mathrm{kg}^{-1} \mathrm{~N} ; \mathrm{Ca}\left(\mathrm{H}_{2} \mathrm{PO}_{4}\right)_{2}$, with 
Table 1. Tillering per pot of Mombasa grass grown in three cuts in Entisol and Ultisol.

\begin{tabular}{lccc}
\hline Soils & First cut $\left(\right.$ tiller pot $^{-1}$ ) & Second cut (tiller pot ${ }^{-1}$ ) & Third cut (tiller pot $^{-1}$ ) \\
\hline Entisol & $28.9 \mathrm{~B}$ & $33.2 \mathrm{~B}$ & $37.7 \mathrm{~B}$ \\
Ultisol & $33.2 \mathrm{~A}$ & $39.6 \mathrm{~A}$ & $44.1 \mathrm{~A}$ \\
DMS & $2.4^{*}$ & $3.2^{*}$ & $3.8^{*}$ \\
$\mathrm{CV} \%$ & 13.2 & 14.9 & 16.0 \\
Chelate $\mathrm{Zn}^{\mathrm{ns}}$ & $31.0( \pm 4.6)^{\mathrm{a}}$ & $36.4( \pm 6.5)$ & $40.9( \pm 7.8)$ \\
$\mathrm{ZnSO}_{4}$ & $35.8( \pm 4.0)$ & $36.4( \pm 3.6)$ & $37.9( \pm 6.6)$ \\
\hline
\end{tabular}

ns: $\mathrm{Zn}$ rates was not significant at $p \leq .05$.

${ }^{\mathrm{a}}$ Standard deviation.

*Significant at $5 \%$ by the Tukey test.

$180.0 \mathrm{mg} \mathrm{kg}^{-1} \mathrm{P}$; dipotassium sulfate $\left(\mathrm{K}_{2} \mathrm{SO}_{4}\right)$, with $150.0 \mathrm{mg} \mathrm{kg}^{-1} \mathrm{~K}$; boric acid $\left(\mathrm{H}_{3} \mathrm{BO}_{3}\right)$, with $0.5 \mathrm{mg} \mathrm{kg}^{-1} \mathrm{~B}$; copper sulfate $\left(\mathrm{CuSO}_{4}\right)$, with $1.0 \mathrm{mg} \mathrm{kg}^{-1} \mathrm{Cu}$; iron sulfate $\left(\mathrm{FeSO}_{4}\right)$, with $10.0 \mathrm{mg}$ $\mathrm{kg}^{-1} \mathrm{Fe} ; \mathrm{H}_{2} \mathrm{MoO}_{4}$, with $0.1 \mathrm{mg} \mathrm{kg}{ }^{-1} \mathrm{Mo}$; manganese sulfate $\left(\mathrm{MnSO}_{4}\right)$, with $3.0 \mathrm{mg} \mathrm{kg} \mathrm{kn}^{-1}$. $4.0 \mathrm{~kg}$ of the treated soils were then transferred to the treatment labeled pots, and after one day Mombasa grass was sown and the seeds were evenly covered with a thin soil depth. After 2 weeks, the plants were thinned to four plants per pot. Soil moisture was maintained close to $80 \%$ field capacity (FC) by daily irrigation with deionized water. The amount of water to be added was determined by weighing the five pots.

The water volume for the application of foliar nutrients was $200 \mathrm{~L} \mathrm{ha}^{-1}$ of $\mathrm{H}_{2} \mathrm{O}$, and 10 sprays of foliar fertilizer per pot were administered, which represented about $5.0 \mathrm{~mL} \mathrm{pot}^{-1}$. During this application, the surface of the pot was protected with tissue paper and cotton was put around the stems to prevent nutrient contact with the soil. Zn was applied 17 days after the germination and one week after each cut.

The plants were cut $5.0 \mathrm{~cm}$ above the soil surface and three cuts were made. The first cut was 34 days after sowing. Then the second and the third cuts were carried out after 28 and 32 days of growth, respectively. Plant material was dried at $65^{\circ} \mathrm{C}$ at constant weight to determine the SDW. The number of tillers was counted at cutting. The dried plant material was ground in a Willey mill and the total content of $\mathrm{Zn}, \mathrm{K}, \mathrm{Ca}$, and $\mathrm{Mg}$ were determined (Malavolta, Vitti, and Oliveira 1997) in the first and third cut.

\section{Statistical analysis}

Data were tested for normality and homogeneity of variance errors and statistical analysis were performed using SAS (Statistical Analysis System, version 8.2; SAS Inc, Cary, NC). The results were submitted to ANOVA, F test and Tukey's multiple comparison of averages, the $5 \%$ of probability. Regression analysis was performed according to the doses of zinc (Pimentel-Gomes and Garcia 2002).

\section{Results and discussion}

\section{Tillers, shoot dry weight yield, and morphological composition}

Tillering results showed no significant effect for $\mathrm{Zn}$ rates via leaf fertilizer (Table 1). The higher yield of tillers e dry weight with Ultisol is possibly associated with greater natural fertility in relation to Entisol (Table 1). The lack of tillering response has been observed in other studies carried out with Marandu grass (Beraldo et al. 2012; Martins, Monteiro, and Pedreira 2014). Thus, further studies are needed with $\mathrm{Zn}$ foliar application, since the absence of responses in the production of tillers and dry weight of Mombasa grass can be connected to experimental conditions with potted content $4.0 \mathrm{dm}^{-3}$ of soil. 
Table 2. Shoot dry weight of Mombasa grass grown in three cuts and total dry weight (TDW) in Entisol and Ultisol.

\begin{tabular}{lcccc}
\hline Soils & First cut $\left(\mathrm{g} \mathrm{pot}^{-1}\right)$ & Second cut $\left(\mathrm{g} \mathrm{pot}^{-1}\right)$ & Third cut $\left(\mathrm{g} \mathrm{pot}^{-1}\right)$ & TDW $\left(\mathrm{g} \mathrm{pot}^{-1}\right)$ \\
\hline Entisol & $14.3 \mathrm{~A}$ & $28.1 \mathrm{~B}$ & $36.5 \mathrm{~B}$ & $78.9 \mathrm{~B}$ \\
Ultisol & $13.2 \mathrm{~B}$ & $30.2 \mathrm{~A}$ & $39.1 \mathrm{~A}$ & $82.5 \mathrm{~A}$ \\
DMS & $0.9^{*}$ & $1.3^{*}$ & $1.8^{*}$ & $2.6^{*}$ \\
$\mathrm{CV} \%$ & 11.0 & 7.8 & 8.1 & 5.6 \\
Chelate $\mathrm{Zn}^{\mathrm{ns}}$ & $13.7( \pm 1.5)^{\mathrm{a}}$ & $29.2( \pm 2.4)$ & $37.8( \pm 3.4)$ & $80.7( \pm 4.7)$ \\
ZnSO $_{4}$ & $14.3( \pm 2.1)$ & $30.0( \pm 1.0)$ & $37.9( \pm 3.4)$ & $82.2( \pm 5.3)$ \\
\hline
\end{tabular}

ns: $\mathrm{Zn}$ rates was not significant at $p \leq .05$.

${ }^{\mathrm{a}}$ Standard deviation.

*Significant at $5 \%$ by the Tukey test.

Table 3. Morphological composition [leaf blade/(stem + sheaths)] in three cuts by Mombasa grass grown in Entisol and Ultisol fertilized with $\mathrm{Zn}$ leaf rates.

\begin{tabular}{|c|c|c|c|c|c|c|}
\hline \multirow[b]{2}{*}{ Treatments } & \multicolumn{2}{|c|}{ First cut } & \multicolumn{2}{|c|}{ Second cut } & \multicolumn{2}{|c|}{ Thirdcut } \\
\hline & Leaf blade (\%) & Stem + sheaths (\%) & Leaf blade (\%) & Stem + sheaths (\%) & Leaf blade (\%) & Stem + sheaths $(\%)$ \\
\hline$\overline{\text { Entisol }^{\text {ns }}}$ & $74.4( \pm 2.3)^{a}$ & $25.6( \pm 2.3)$ & $76.8( \pm 1.0)$ & $23.2( \pm 1.0)$ & $75.1( \pm 0.9)$ & $24.9( \pm 0.9)$ \\
\hline Ultisol $^{\text {ns }}$ & $77.9( \pm 2.1)$ & $22.1( \pm 2.1)$ & $75.8( \pm 1.0)$ & $24.3( \pm 0.9)$ & $76.1( \pm 0.7)$ & $23.9( \pm 0.7)$ \\
\hline Chelate $\mathrm{Zn}^{\mathrm{ns}}$ & $76.2( \pm 2.2)$ & $23.8( \pm 2.2)$ & $76.3( \pm 0.9)$ & $23.7( \pm 0.9)$ & $75.6( \pm 1.0)$ & $24.4( \pm 1.0)$ \\
\hline $\mathrm{ZnSO}_{4}{ }^{\mathrm{ns}}$ & $75.7( \pm 1.6)$ & $24.4( \pm 1.6)$ & $75.9( \pm 0.6)$ & $24.1( \pm 0.6)$ & $75.7( \pm 1.0)$ & $24.3( \pm 1.0)$ \\
\hline
\end{tabular}

ns: $\mathrm{Zn}$ rates was not significant at $p \leq .05$.

${ }^{\text {a }}$ Standard deviation.

However, differential responses between the soils were observed, with higher tillering in Ultisol. The SDW followed the same trend of tillering with higher yield (Table 2). These results were a consequence of greater tillering. In the morphological separation [(blade leaf/ $($ stem + sheath)] variation was not observed due to the foliar fertilization and soil (Table 3 ).

\section{Root dry weight}

There was a significant interaction with the $\mathrm{Zn}$ rates applied and the types of soil used for the roots dry weight (RDW) yield. Overall, Entisol had the highest average ranging from 150.6 to $56.6 \mathrm{~g} \mathrm{pot}^{-1}$ at 87 and $696 \mathrm{~g}$ rates of $\mathrm{Zn}$ chelate, respectively. While averages Ultisol were lower,

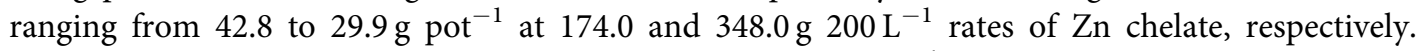
Treatment with $\mathrm{ZnSO}_{4}$, RDW yield was 34.6 and $207.5 \mathrm{~g} \mathrm{pot}^{-1}$ for Ultisol and Entisol, respectively (Figure 1A,B).

In Ultisol, there was no effect of $\mathrm{Zn}$ rates in $\mathrm{RDW}$ yield, while in Entisol a reduction in the RDW occurred in the larger leaf $\mathrm{Zn}$ levels (Figure 1). This confined the roots to a small space with greater contact root-soil and provided greater nutrients utilization from the soil or plant. As a result, it could not express its maximum yield potential and, hence, the nutrient content in the soil was sufficient. It is possible that the Ultisol with an average $\mathrm{Zn}$ content in the soil had enough of this micronutrient to meet the physiological needs of plants, maintaining the same RDW yield, independent to the rate applied to the leaves. On the other hand, in Entisol low Zn content in the soil and the presence of the micronutrients foliar application reduced RDW yield, which may be associated with less need for uptake via the roots (Christophersen and Lyons 2012).

\section{Zinc and potassium concentration}

The chelated $\mathrm{Zn}$ application linearly increases micronutrient concentrations in the shoots of Mombasa grass in the first cut, with no significant difference between the soils. The levels ranged

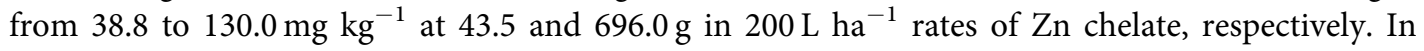



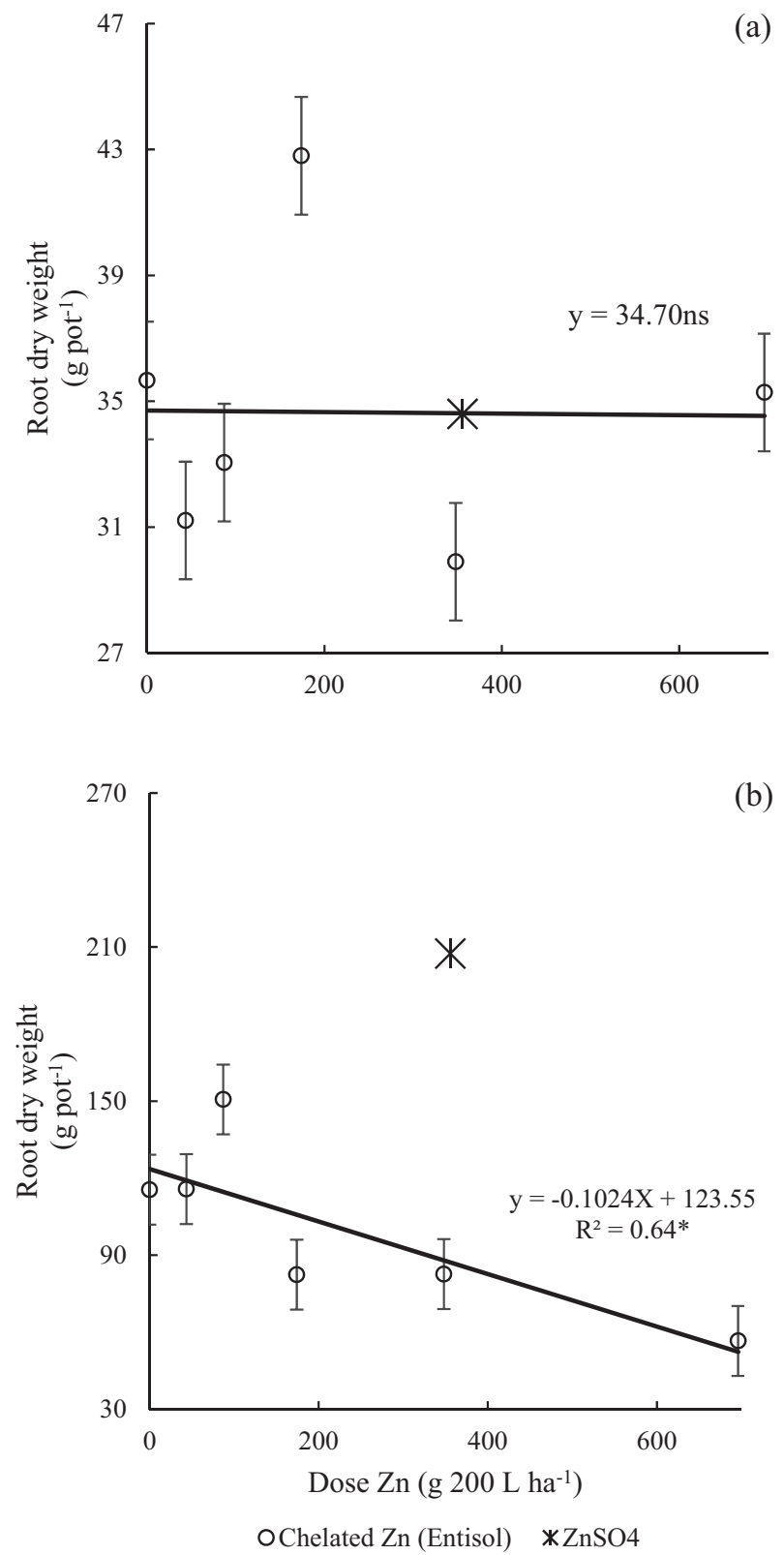

Figure 1. Root dry weight yield of Megathyrsus maximum cv. Mombasa with chelated Zn rates. a: Cultivated in Ultisol. b: Cultivated in Entisol.

the treatments with $\mathrm{ZnSO}_{4}$, the concentration of $88.8 \mathrm{mg} \mathrm{kg}^{-1} \mathrm{Zn}$ at $355.0 \mathrm{~g} 200.0 \mathrm{~L}^{-1}$ rate was obtained (Figure 2A).

In the third cut, the $\mathrm{Zn}$ content in the plant showed a significant interaction between the dose of chelated $\mathrm{Zn}$ and soil, ranging from 12.5 to $138.5 \mathrm{mg} \mathrm{kg}^{-1}$ in Entisol and 39.2 to $262.3 \mathrm{mg} \mathrm{kg}^{-1}$

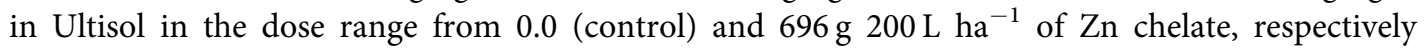
(Figure 2B,C).

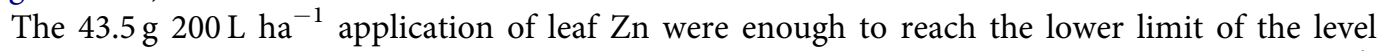
considered appropriate for $\mathrm{Zn}$ in the shoots of Mombasa grass, ranging from 20 to $50 \mathrm{mg} \mathrm{kg}^{-1}$, as well, when grown in Entisol with micronutrient deficiency $\left(\leq 0.3 \mathrm{mg} \mathrm{dm}^{-3}\right)$. The results show 
(a)

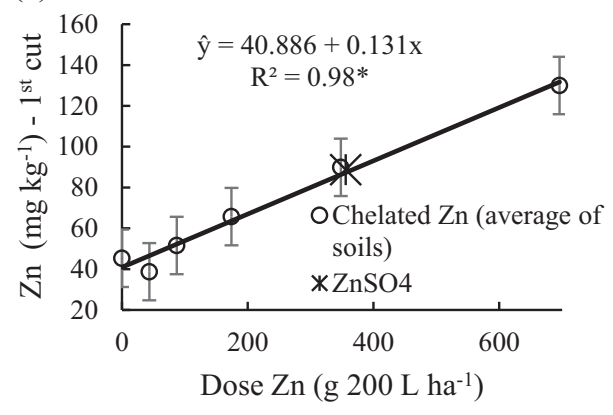

(c)

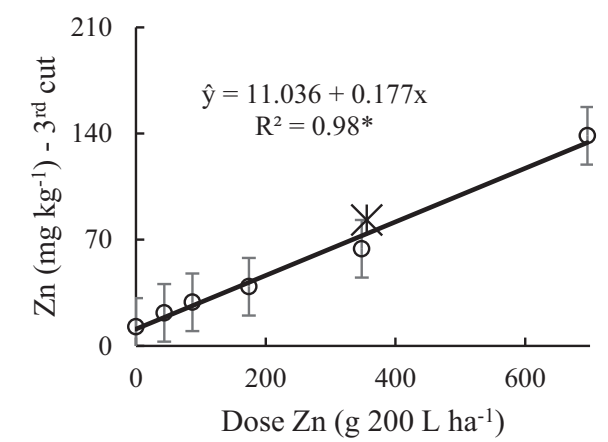

(b)

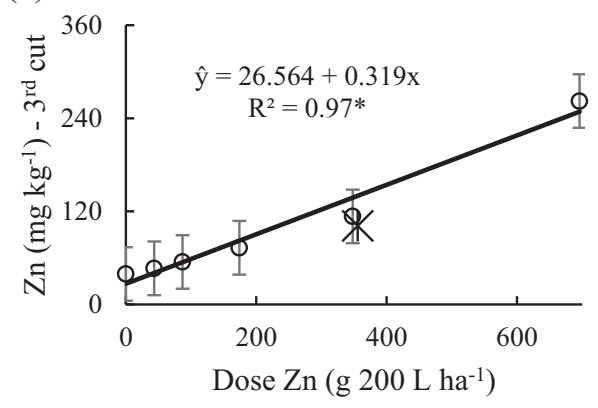

(d)

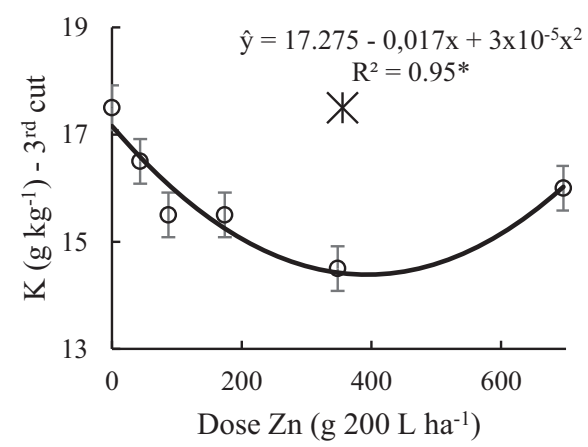

Figure 2. $\mathrm{Zn}$ and $\mathrm{K}$ concentration in Megathysus maximum cv. Mombasa due to foliar rate of chelated $\mathrm{Zn}$ grown in Ultisol and Entisol. a: $\mathrm{Zn}$ in the first cut to the average of the two soil types; b: $\mathrm{Zn}$ in the third cut the forage grown in Ultisol; c: $\mathrm{Zn}$ in the third cut the forage grown in Entisol; $d$ : $\mathrm{K}$ in the third cut the forage grown in Entisol.

Table 4. $\mathrm{K}, \mathrm{Ca}$, and $\mathrm{Mg}$ concentration in Mombasa grass in first and third cutting in Entisol and Ultisol.

\begin{tabular}{lccc}
\hline Soils & $\mathrm{K}\left(\mathrm{g} \mathrm{kg}^{-1}\right)$ & $\mathrm{Ca}\left(\mathrm{g} \mathrm{kg}^{-1}\right)$ & $\mathrm{Mg}\left(\mathrm{g} \mathrm{kg}^{-1}\right)$ \\
\hline First cutting & & & 7.7 \\
Entisol & $22.8 \mathrm{~B}$ & $6.8 \mathrm{~A}$ & 8.0 \\
Ultisol & $30.3 \mathrm{~A}$ & $5.8 \mathrm{~B}$ & $0.4^{\mathrm{ns}}$ \\
DMS & $1.7^{*}$ & $0.7^{*}$ & 8.6 \\
$\mathrm{CV} \%$ & 11.1 & 18.2 & $7.8( \pm 0.6)$ \\
Chelate Zn & $\mathrm{ns}$ & $6.3( \pm 0.8)$ & $7.7( \pm 0.5)$ \\
ZnSO $_{4}$ & $26.5( \pm 1.9)^{\mathrm{a}}$ & $7.4( \pm 1.3)$ & \\
Third cutting & $25.0( \pm 5.3)$ & & $2.0 \mathrm{~B}$ \\
Entisol & & 7.4 & $2.2 \mathrm{~A}$ \\
Ultisol & $16.3 \mathrm{~B}$ & 7.4 & $0.1^{*}$ \\
DMS & $18.8 \mathrm{~A}$ & $0.4^{\mathrm{ns}}$ & 10.4 \\
CV\% & $1.2^{*}$ & 9.4 & $2.1( \pm 0.2)$ \\
Chelate $\mathrm{Zn}^{\mathrm{ns}}$ & 11.8 & $7.3( \pm 0.5)^{\mathrm{a}}$ & $2.0( \pm 0.2)$ \\
ZnSO & - & $6.3( \pm 0.9)$ &
\end{tabular}

ns: $\mathrm{Zn}$ rates was not significant at $p \leq .05$.

${ }^{\text {as }}$ Standard deviation.

* Significant at $5 \%$ by the Tukey test.

that the leaf fertilization with $\mathrm{Zn}$ can contribute to the nutrition of Mombasa grass (Martins, Monteiro, and Pedreira 2015) and contribute to the forage yield of better quality minerals for animals. In the $\mathrm{Zn}$ analysis results in the control treatment $(0 \mathrm{Zn})$, in the first and third cut it is possible to verify the reduction of the micronutrients concentration in the SDW as a function of successive cuts (Figure $2 \mathrm{~A}-\mathrm{C}$ ), suggesting the need for replacement of the nutrient in the system to maintain mineral forage quality. 

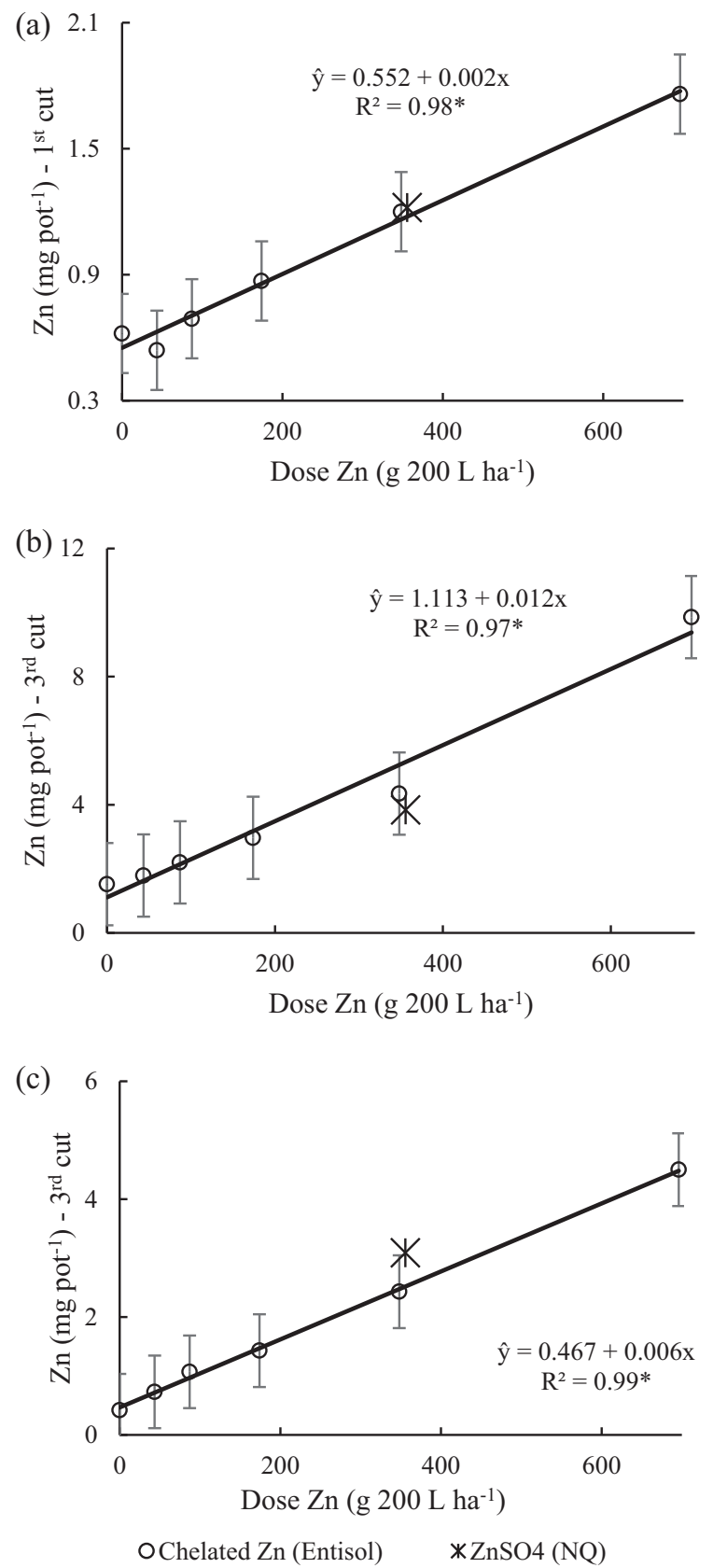

Figure 3. Zn and K uptake by Megathysus maximum cv. Mombasa due to foliar rate of chelated Zn grown in Ultisol and Entisol: $\mathrm{a}: \mathrm{Zn}$ in the first cut to the average of the two soils; $b: \mathrm{Zn}$ in the third cut the forage grown in Ultisol; $c: \mathrm{Zn}$ in the third cut the forage grown in Entisol.

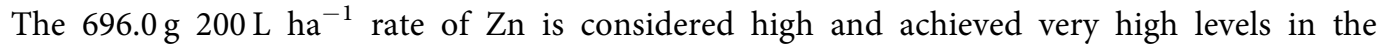
plant (Figure 2A-C). However, toxicity symptoms were not observed. No references were found of $\mathrm{Zn}$ levels that would be toxic to the Mombasa grass, but forage grasses adequate levels are usually cited up to $50.0 \mathrm{mg} \mathrm{kg}^{-1}$ (Raij et al. 1996). It is possible that $\mathrm{Zn}$, when retained in vacuoles and complexed with organic acids, reduces or prevents its toxicity (Shanti, Dietz, and Mimura 2016). 
Table 5. K, Ca, and Mg Uptake in Mombasa grass in first and third cutting in Entisol and Ultisol.

\begin{tabular}{llcc}
\hline Soils & $\mathrm{K}\left(\mathrm{g} \mathrm{pot}^{-1}\right)$ & $\mathrm{Ca}\left(\mathrm{g} \mathrm{pot}^{-1}\right)$ & $\mathrm{Mg}\left(\mathrm{g} \mathrm{pot}^{-1}\right)$ \\
\hline First cutting & & & \\
Entisol & $0.32 \mathrm{~B}$ & $0.09 \mathrm{~A}$ & 0.11 \\
Ultisol & $0.39 \mathrm{~A}$ & $0.07 \mathrm{~B}$ & 0.10 \\
DMS & $0.02^{*}$ & $0.01^{*}$ & $0.01^{\mathrm{ns}}$ \\
CV\% & 11.7 & 21.03 & 15.06 \\
Chelate Zn & $6.28( \pm 0.78)$ & $7.84( \pm 0.58)$ \\
ZnSO $_{4}$ & $26.54( \pm 1.91)^{\mathrm{a}}$ & $7.43( \pm 1.31)$ & $7.68( \pm 0.51)$ \\
Third cutting & $25.00( \pm 5.29)$ & & $0.26 \mathrm{~B}$ \\
Entisol & & $0.28 \mathrm{~A}$ & $\mathrm{~B}$ \\
Ultisol & $0.63 \mathrm{~B}$ & $0.01^{*}$ & $0.08 \mathrm{~A}$ \\
DMS & $0.71 \mathrm{~A}$ & 10.27 & $0.005^{*}$ \\
CV\% & $0.04^{*}$ & $0.27( \pm 0.18)$ & 10.70 \\
Chelate Zn & 13.65 & $0.26( \pm 0.36)$ & $0.07( \pm 0.19)$ \\
ZnSO $_{4}$ & $0.69( \pm 0.15)^{\mathrm{a}}$ & & $0.07( \pm 0.03)$ \\
\hline
\end{tabular}

ns: $\mathrm{Zn}$ rates was not significant at $p \leq .05$.

${ }^{\text {a }}$ Standard deviation.

*Significant at $5 \%$ by the Tukey test.

In relation of the $\mathrm{K}$, was observed lower concentration with higher $\mathrm{Zn}$ rate in Entisol (Figure 2D), may be associated with similar effects observed in the $\mathrm{Mg}$ to $\mathrm{Zn}$ inhibition (Moreira et al. 2003, 2005). There also may be some inhibition of the $\mathrm{K}$ uptake due to high $\mathrm{Zn}$ rates. However, more studies are necessary on ionic competition, especially involving micronutrients (Marschner 2012).

In the first cut, the $\mathrm{K}$ content in the shoots was higher when cultivated in Ultisol $\left(30.3 \mathrm{~g} \mathrm{~kg}^{-1}\right)$ compared to Entisol $\left(22.8 \mathrm{~g} \mathrm{~kg}^{-1}\right)$. In the third cut, the Ultisol continued with the highest average $\left(18.8 \mathrm{~g} \mathrm{~kg}^{-1}\right), 15 \%$ higher than the Entisol (Table 4). The difference between the soils can be attributed to the higher natural fertility of Ultisol. In Entisol, the $\mathrm{K}$ content in the shoots of Mombasa grass of the third cut was significant. The minimum point of $14.8 \mathrm{~g} \mathrm{~kg}^{-1} \mathrm{~K}$ at $288 \mathrm{~g}$ $200 \mathrm{~L} \mathrm{ha}^{-1}$ rate of $\mathrm{Zn}$ chelate was observed (Figure 2D).

The Ca content in both soils and cuts is within the desired range. Meanwhile, $\mathrm{Mg}$ showed high concentration in the first cut and reduction in the subsequent cut (Table 4). These results may suggest the need for replacement of the nutrients in crops with high technology, because the amount provided via liming cannot meet the demand of the plant. Although there was a difference between the soil in $\mathrm{Ca}$ and $\mathrm{Mg}$, in all cases they are within the same range of interpretation. Regarding $\mathrm{Zn}$ rates, no effect on the $\mathrm{Ca}$ and $\mathrm{Mg}$ concentration in forage was observed. The results were very close to those seen with the $\mathrm{ZnSO}_{4}$ application (Table 4).

\section{Uptake of zinc and potassium}

The $\mathrm{Zn}$ uptake during the first growth cycle of Mombasa grass showed a linear response as a function of foliar fertilization of $696 \mathrm{~g}^{2} 00 \mathrm{~L} \mathrm{ha}^{-1} \mathrm{Zn}$ chelate and no difference between the soils (Figure 3A). In turn, the third cut produced a differential response as a function of the soil, with higher absorption in Ultisol compared to Entisol, although both showed a linear response. As described above, the highest values found in Ultisol should be related to the higher contribution of the nutrients in the soil (Figure 3B,C). Regarding the additional treatment with $\mathrm{ZnSO}_{4}$, the content found in plants was very similar to that observed with the chelated $\mathrm{Zn}$ application.

Regarding the cationic elements $\mathrm{K}, \mathrm{Ca}$, and $\mathrm{Mg}$, results showed that the largest amounts were absorbed in Ultisol with the exception of the first cut, when the Ca values were higher in Entisol and $\mathrm{Mg}$ showed no difference between soils (Table 5). According to NRC (1996) the values $30.0 \mathrm{mg} \mathrm{kg}^{-1} \mathrm{Zn}, 6.0 \mathrm{~g} \mathrm{~kg}^{-1} \mathrm{~K}^{-1}, 1.2 \mathrm{~g} \mathrm{~kg}^{-1} \mathrm{Ca}$, and $1.0 \mathrm{~g} \mathrm{~kg}^{-1} \mathrm{Mg}$ supply the daily necessities for a calf of $350 \mathrm{~kg}$. As a result, it is possible to note that the fertilizer used provided the growth and forage production with a nutrient concentration that would ensure proper animal nutrition, 
particularly in relation to $\mathrm{Zn}$. In the absence of foliar fertilization, the levels were well below the reference value previously mentioned. Overall, the results of increased nutrients uptake in Ultisol may be associated with different physicochemical characteristics of the soil, such as clay content, presence of oxides and original nutrient content in the soil, among others (Melo et al. 2016).

\section{Conclusions}

The zinc chelate and zinc sulfate foliar application did not affect the shoot dry weight (SDW) yield of Mombasa grass. The tillering and SDW was higher in Ultisol than in Entisol. The Zn content in the dry weight of Mombasa grass was directly proportional to the rate chelated $\mathrm{Zn}$ foliar, contributing to the yield of better quality forage. The root dry weight of Mombasa grass was reduced with the chelated Zn foliar application in Entisol and had no effect on Ultisol. Further research is needed to evaluate the ionic competition of cationic nutrients, especially involving $\mathrm{Zn}$ and foliar fertilization.

\section{References}

Beraldo, J. M. G., R. M. Prado, J. W. M. Cortez, A. J. R. Mello, and C. A. K. Taniguchi. 2012. Production and nutrition of Marandu grass submitted to doses of zinc in soil. Revista Biotemas 25:1-7.

Boonchuay, P., I. Cakmak, B. Rerkasem, and C. Prom-U-Thai. 2013. Effect of different foliar zinc application at different growth stages on seed zinc concentration and its impact on seedling vigor in rice. Soil Science and Plant Nutrition 59(2):180-8. doi: 10.1080/00380768.2013.763382.

Christophersen, O. A., and G. Lyons. 2012. Selenium. In Heavy metals in soils: Trace elements and metalloids in soils and their bioavailability, ed. B. J. Alloway, 175-200. 3rd ed. Dordrecht, The Netherlands: Springer.

Embrapa (Empresa Brasileira de Pesquisa Agropecuária). 2013. Brazilian system of soil classification. Rio De Janeiro, Brazil: Embrapa Solos.

Guimarães, G. G. F., R. L. Mulvaney, R. B. Cantarutti, B. C. Teixeira, and L. Vergütza. 2016. Value of copper, zinc, and oxidized charcoal for increasing forage efficiency of urea $\mathrm{N}$ uptake. Agriculture, Ecosystems \& Environment 224:157-65. doi: 10.1016/j.agee.2016.03.036.

Heinrichs, R., C. M. Monreal, E. T. Santos, C. V. Soares Filho, M. D. Rebonatti, N. M. Teixeira, and A. Moreira. 2016. Phosphorus sources and rates associated with nitrogen fertilization in Mombasa grass yield. Communications in Soil Science and Plant Analysis 47(5):657-69. doi: 10.1080/00103624.2016.1141923.

Jha, C. K., S. K. Sinha, M. Alam, and S. S. Pandey. 2015. Effect of bio-compost and zinc application on sugarcane (Saccharum species hybrid complex) productivity, quality and soil health. Indian Journal of Agronomy 60:450-6.

Malavolta, E., G. C. Vitti, and S. A. Oliveira. 1997. Evaluation of nutritional status of plants; principles and application [avaliação do estado nutricional das plantas: princípios e aplicações]. Piracicaba, Brazil: Potafós.

Manoj, K., A. K. Jha, S. Hazarika, B. C. Verma, B. U. Choudhury, T. Ramesh, P. Moirangthem, R. Kumar Brajendra, D. J. Rajkhowa, A. Kumar, and M. H. Devi. 2016. Micronutrients (B, Zn, Mo) for improving crop production on acidic soils of northeast India. National Academy Science Letters 39:85-9.

Marschner, P. 2012. Mineral nutrition of higher plants. London, UK: Academic Press.

Martins, L. E. C., F. A. Monteiro, and B. C. Pedreira. 2014. Metabolic change, tillering and root system of Brachiaria brizantha in response to phosphorus and zinc nutrition. Journal of Plant Nutrition 37(4):509-19. doi: 10.1080/01904167.2013.867979.

Martins, L. E. C., F. A. Monteiro, and B. C. Pedreira. 2015. Photosynthesis and leaf area of Brachiaria brizantha in response to phosphorus and zinc nutrition. Journal of Plant Nutrition 38(5):754-67. doi: 10.1080/ 01904167.2014.939758.

Melo, L. C. A., A. P. Puga, A. R. Coscione, L. Beesley, C. A. Abreu, and O. A. Camargo. 2016. Sorption and desorption of cadmium and zinc in two tropical soils amended with sugarcane-straw-derived biochar. Journal of Soils and Sediments 16(1):226-34. doi: 10.1007/s11368-015-1199-y.

Moreira, A., E. Malavolta, R. Heinrichs, and R. T. Tanaka. 2003. Magnesium influence on manganese and zinc uptake by excised roots of soybean. Pesquisa Agropecuária Brasileira 38(1):95-101. doi: 10.1590/S0100$204 X 2003000100013$.

Moreira, A., J. G. Carvalho, and A. R. Evangelista. 2005. Calcium and magnesium ratio in the fertility of a dystrophic yellow red latosol cultivated with alfalfa. Ciência e Agrotecnologia 29(4):786-95. 
Moreno, L. S. B., C. G. S. Pedreira, K. J. Boote, and R. R. Alves. 2014. Base temperature determination of tropical Panicum spp. grasses and its effects on degree-day-based models. Agricultural and Forest Meteorology 186: 26-33. doi: 10.1016/j.agrformet.2013.09.013.

NRC (National Research Council). 1996. Nutrient requirements of beef cattle. Washington, D.C.: National Academy of Science.

Pimentel-Gomes, F., and C. H. Garcia. 2002. Estatística aplicada a experimentos agronômicos e florestais. Piracicaba, Brazil: FEALQ.

Raij, B., H. Cantarella, J. A. Quaggio, and A. M. C. Furlani. 1996. Recomendações de adubação e calagem Para o estado de São Paulo. Campinas, Brazil: Instituto Agronômico de Campinas.

Raij, B., J. C. Andrade, H. Cantarella, and J. A. Quaggio. 2001. Análise química Para avaliação da fertilidade de solos tropicais. Campinas, Brazil: Instituto Agronômico de Campinas.

Shanti, S. S., K. J. Dietz, and T. Mimura. 2016. Vacuolar compartmentalization as indispensable component of heavy metal detoxification in plants. Plant, Cell and Environment 39:1112-26. doi: 10.1111/pce.12706. 